\title{
Mineral Intake Status of Community-Dwelling Elderly from Urban and Rural Areas of South Korea: A Cross-Sectional Study Based on Korean National Health and Nutrition Examination Survey, 2013 2016
}

\author{
Ji-Myung Kim ${ }^{1}\left(\mathbb{D}\right.$ and Yun-Jung Bae ${ }^{2, *}$ (I) \\ 1 Food and Nutrition Major, Division of Food Science and Culinary Arts, Shinhan University, Uijeongbu, \\ Gyeonggi 11644, Korea; kjm@shinhan.ac.kr \\ 2 Major in Food and Nutrition, Division of Food Science and Biotechnology, Korea National University of \\ Transportation, Jeungpyeong 27909, Korea \\ * Correspondence: byj@ut.ac.kr
}

Received: 15 March 2020; Accepted: 12 May 2020; Published: 14 May 2020

\begin{abstract}
We aimed to evaluate the intake of minerals (calcium, phosphorous, sodium, and potassium) in the urban and rural elderly and explore the adequacy of intake and food sources for each mineral using nationwide big data. The study used data from the Korea National Health and Nutrition Examination Survey (KNHANES) between 2013 and 2016. We analyzed 5292 elderly individuals that were aged 65 years and older (2271 men, 3021 women). Daily calcium, phosphorous, sodium, and potassium intake, and they were analyzed using the 24-h dietary recall method. Additionally, the adequacy of intake and food sources for each mineral was analyzed. Blood triglyceride level was significantly higher in rural elderly than in urban elderly. The intake of calcium and potassium per $1000 \mathrm{kcal}$ of energy intake was significantly lower in the rural elderly, and the proportion of participants with calcium intake below the Estimated Average Requirement was significantly higher in the rural elderly than in the urban elderly. The intake of calcium, phosphorous, and potassium in the rural elderly was lower than that in the urban elderly. These results can be used as basic data when making social and environmental policies for the health of the elderly and when providing targeted dietary education for the management of chronic diseases for the elderly.
\end{abstract}

Keywords: calcium; potassium; rural; Korea; elderly

\section{Introduction}

The world population continues to grow older, and the proportion of the world's population over 60 years of age is expected to nearly double from 12\% in 2015 to $22 \%$ in 2050 [1]. In South Korea, 14.3\% of the total population was 65 years old or over in 2018 [2], and there is growing interest in improving the health and quality of life of the elderly to better encounter population aging. Healthy life in the elderly is dependent on their nutritional status, illness, social, psychological, and economic factors [3].

Good nutrition is one of the key considerations of healthy aging [4]. However, previous studies have showed a decrease in food intake in the elderly. The proportion of people with nutritional deficiency, whose energy intake was lower than 75\% of Estimated Energy Requirement and intakes of calcium, iron, vitamin $\mathrm{A}$, and vitamin $\mathrm{B}_{2}$, were lower than the Estimated Average Requirements (EAR) of respective nutrients, was $14.4 \%$, the third highest, in the age group of 65 and older; $17.6 \%$ in the 12-18 age group; and, $16.2 \%$ in the 19-29 age group, according to 2018 Korea National Health and Nutrition Examination Survey (KNHANES) [5] There decrease in the food intake of the elderly is attributed to reduced digestive ability, loss of appetite, poor teeth condition, oral health [6-8], and other 
factors, such as dysphagia, diarrhea, depression, drug, and dysfunction [9]. The level of education and income [10], living alone [11], living area [12], and poor neighborhood food environment [13] are also reported to affect the nutritional status of the elderly.

Elderly health and nutritional status may be associated with dietary differences resulting from urban-rural differences in lifestyles and environmental factors $[12,14,15]$. Each elderly individual is a member of a community and lives in relationships with others based on where the person lives. Accordingly, the area where a person lives is expected to act as a factor that influences the diet and life of the elderly. The relationship of urban-rural dwellings with chronic diseases differed as much as the urban and rural living environment. In a cohort study, urban residence was one of the strong predictors of type 2 diabetes [16]. In postmenopausal women, the incidence rate of osteoporosis of postmenopausal women was significantly higher among rural residents than among urban residents [17]. Health behaviors and status of the elderly vary depending on the region of residence. A study reported that the health behaviors and status of the elderly in rural areas are better than those in urban areas, despite the worse socioeconomic conditions of rural communities [18].

Several non-Korean studies found that the intake of sugar, fat, and animal protein was higher in urban areas, while traditional meals consisting of natural foods were consumed more in rural areas than in urban areas [19-21]. Moreover, in the overall assessment of nutritional status, the proportion of poor nutritional status, as evaluated by Mini Nutritional Assessment (MNA), was higher in the urban elderly than in the rural elderly in France [10]; however, there was no significant difference in malnutrition between urban and rural areas in Poland [14]. In Taiwan, the elderly in rural areas reported to have lower self-rated healthy eating status than the elderly in urban areas [15]. Studies $[10,14,15]$ that reported on the comparison of nutritional status of the elderly between urban-rural areas were mostly based on nutritional screening indicators, such as MNA, although a few previous studies have reported comparison of the actual nutrient intake [22].

Studies in Korea showed significantly higher intake of carbohydrate and sodium among the rural adults that were 40-70 years of age [23], while urban people consumed more sugar-sweetened beverages and fast-food [24]. Studies in the elderly showed westernized and meat-based eating habits among the urban elderly, while the elderly in rural areas had healthier eating habits [25]. Yet, a study found that elderly women in the urban areas had significantly higher quality of nutrient intake than rural dwellers [26]. As such, differences in nutrients and food intake between urban and rural areas were observed in the Korean elderly, but the study results were inconsistent.

Adequate intake of nutrients is suggested for nutritional health to promote healthy aging [27]. The adequate intake of micronutrients (calcium, phosphorous, sodium, and potassium) is closely related to the development of chronic diseases, including hypertension, coronary heart disease, and osteoporosis. Calcium is considered to be a vital nutrient for prevention and management of osteoporosis, obesity, and hypertension [28,29]. Particularly, adequate calcium intake is essential for health maintenance of the elderly when considering adipose tissue accumulation, bone mass loss, and degeneration of blood vessels with aging [30]. Phosphorus deficiency is often observed in patients with prolonged treatment for certain chronic diseases. If elderly without illness are malnourished or are on medications that bind anions, they might suffer from phosphorus depletion [31]. Moreover, the intake of calcium and phosphorus in an appropriate ratio is crucial for the elderly who are at risk of osteoporosis. As the worldwide prevalence of hypertension due to excessive sodium intake continues to be a persistent problem [32], it is very important to maintain proper nutritional status of sodium and potassium in the elderly who are at risk of hypertension that is associated with stiffened blood vessels with aging. Mineral intake in the elderly is associated with their health indicators, as shown in previous studies [30,31]; however, few studies, to date, have compared health indicators between urban and rural elderly and the association between mineral intake and health indicators by regions.

Mineral intake status of the Korean elderly indicated that the mean calcium intake of the elderly aged 65 years and older was $60 \%$ of the Recommended Nutrient Intake (RNI) of calcium, while the mean sodium intake of the same group was $138.2 \%$ of the Goal Intake (GI) of sodium (2000 mg) as 
maximum threshold, thus posing as a prominent risk factor [5]. Additionally, only few studies have focused on the evaluation of mineral intake in the Korean urban and rural elderly, where differences in food intake and some nutrient intake have been reported [22]. Lee et al. [22] reported no significant urban-rural differences in calcium, sodium, and potassium intake after analysis of each mineral based on the RNI. However, another previous study has noted that nutrient intake in the elderly varied depending on the location and gender effect [20]; it is assumed that mineral intake is supposedly different between men and women and between urban and rural settings. We focused on performing an in-depth study on the differences in health status and mineral intake in elderly people, particularly between those living in urban and rural areas, noting the importance of adequate mineral intake in maintaining the health of elderly people. Accordingly, the following strategies were implemented. First, we planned to assess the differences in health indicators between elderly people living in urban and rural areas for promoting their health. Second, we intended to evaluate the adequacy of mineral intake in elderly people living in urban and rural areas to identify minerals that are inadequately consumed in this population. Third, we sought to identify food sources, when considering the unique eating patterns in the Korean population, which contribute to mineral intake to provide basic data for future interventions targeting elderly people living in urban and rural areas with respect to adequate mineral intake. Additional research on the differences in food sources of mineral intake between urban and rural elderly is necessary due to the inconsistencies in results obtained and the unique dietary patterns in Korea. In addition, studies on the comparison of health indicators in urban-rural elderly and the relationship between mineral intake and health indicators are needed. Therefore, we aimed to evaluate the intake of minerals (calcium, phosphorous, sodium, and potassium) in the urban and rural elderly and explore the adequacy of intake and food sources for each mineral while using nationwide big data.

\section{Methods}

\subsection{Study Design and Participants}

This was a cross-sectional study that analyzed data that were obtained from participants of the KNHANES VI (2013-2015) and VII-1 (2016) conducted from January 2013 to December 2016 by the Korea Centers for Disease Control and Prevention [33]. The KNHANES VI (2013-2015) and VII-1 (2016) was a nationwide, representative survey of 31,098 people from 13,004 households. Survey participants were randomly selected while using a multistage clustered and stratified random sampling method with proportional allocation based on geographic area, sex, and age group from the National Census Data. Survey design and data collection procedures are available elsewhere [34]. The KNHANES consisted of three sections: a health and behavior interview, a health examination, and a dietary survey. We excluded participants who did not respond to dietary surveys $(n=3385)$, those under 65 years $(n=22,233)$, and those who reported implausible daily energy intake $(<800$ or $>4000 \mathrm{kcal} /$ day in men, $<500$ or $>3500 \mathrm{kcal} /$ day in women $)(n=188)$ [35]. Subsequently, a total of 5292 participants (2271 men and 3021 women) were analyzed in the present study. The Institutional Review Board of the Korea Centers for Disease Control and Prevention (2013-07CON-03-4C, 2013-12 EXP-03-5C) for the years 2013 and 2014 approved this study, as the 2015 KNHANES was exempted from research ethics approval based on the Bioethics and Safety Act. Written informed consent was obtained from all of the study participants.

\subsection{Data Collection}

Socio-demographic factors, such as age, sex, living area, education, income, marital status, nutrition education, and residence, were collected using a self-reported general questionnaire. The smoking status and alcohol consumption data were collected while using health and behavior interview. Living area of the aged was classified into two groups: urban and rural. Household income was classified into four groups: low, middle-low, middle-high, and high. The educational level was determined by three 
categories in accordance with their graduation status (either elementary school, middle school, or high school or higher). Marital status was categorized by married or other, including single, separated, divorced, widowed, and cohabiting. Smoking status was classified as current or past/never. Alcohol intake was determined by four categories in accordance with their frequency of alcohol consumption (never, $\leq 1 /$ month, $2-4 /$ month, $\geq 2 /$ week). Nutrition education was classified as "yes" or "no".

Anthropometric data, blood pressure, and blood profiles were collected while using health examination. Body mass index (BMI) was calculated as weight $(\mathrm{kg})$ divided by height $(\mathrm{m})$ squared $\left(\mathrm{kg} / \mathrm{m}^{2}\right)$. Participants were classified into three categories based on BMI $\left(\mathrm{kg} / \mathrm{m}^{2}\right):<23,23 \leq$ BMI $>25$, or $\geq 25$. Blood pressure was measured three times using a mercury sphygmomanometer (Baumanometer; Baum Co., Copiague, NY, USA). Using fasting blood samples, total cholesterol, HDL-cholesterol, triglyceride, and glucose were directly measured using a Hitachi Automatic Analyzer 7600 (Hitachi, Tokyo, Japan). LDL-C was calculated using Friedewald's equation for participants with no data on LDL-C [36]. Hemoglobin was directly measured using a XE-2100D in 2013-2014 and using a XN-9000 in 2015-2016 reports (Sysmex, Kobe, Japan).

Dietary intake data were obtained using a 24-h dietary recall protocol as part of the dietary survey. The dietary data were collected by trained dietitians at the participant's home, one week after the health interview survey and health examination survey were completed. The total energy and nutrient intake were calculated while using a food composition table that was published by the Rural Development Administration of Korea [37]. The 2015 Dietary Reference Intakes (DRI) for Koreans [38] was used to determine energy and mineral intake status. Macronutrient intake was evaluated as a percentage of total energy intake (\% kcal).

\subsection{Outcome Measure}

Nutrient density, nutrient amount per $1000 \mathrm{kcal}$, was calculated for calcium, phosphorous, potassium, and sodium. The mineral intake levels were determined by three categories; $<75 \%$, $75-125 \%$, or $>125 \%$ based on the Recommended Nutrient Intake (RNI) for calcium and phosphorus and Adequate Intake (AI) for potassium: Prevalence of insufficient intake was calculated for calcium, phosphorous, and potassium. Insufficient intake was deduced if the mineral intake level was less than the corresponding EAR and RNI for calcium and phosphorus or AI for potassium. The prevalence of excessive intake of sodium was calculated by comparing with GI of $2000 \mathrm{mg}$. The ratio of calcium to phosphorus was calculated as calcium intake divided by phosphorus intake. The tertiary food codes of the KNHANES were used to identify major food sources of minerals. Food sources of minerals were identified based on the mineral content in each food. The major food sources were determined by taking the ratio of minerals provided by each food over the total intake of mineral from all foods.

\subsection{Statistical Analysis}

All of the statistical analyses were performed while using the SAS software version 9.4 (SAS Institute, Cary, NC, USA). All of the analyses accounted for the complex survey design, which consisted of multistage, stratified, and clustered samples and survey weights to reflect the estimates of the entire Korean population and avoid biased results. The participants were categorized into two groups, depending on the living area: (1) urban group and (2) rural group. The analyses were separately conducted for men, women, and the total participants. The intake of total energy, macronutrients, and minerals was expressed as mean \pm standard error and the food sources of mineral were presented with percentages and cumulative percentages of total consumption. Categorical variables, including age, education, income, marital status, alcohol intake, smoking, nutrition education, BMI categories, and mineral intake categories, were expressed as frequencies and percentages and then compared between the urban and rural groups while using the chi-square test. The blood profiles and intake of minerals by living area was analyzed using the general linear model after adjustment for age, household income level, education level, and total energy intake. The total participants were additionally adjusted for sex variable. $p$-values $<0.05$ were considered to be significant. 


\section{Results}

Table 1 shows the general characteristics of the participants. The mean age was significantly higher in the rural elderly than in the urban elderly ( $p<0.001$ in men; in women; and, in the total), and the proportion of population over 75 years old was significantly higher in rural areas than in urban areas ( $p=0.001$ in men; $p<0.001$ in women; and, in the total). The rural participants had significantly lower rates of education and lower household incomes $(p<0.001$ in men, women, and in the total sample for both the categories). The rural elderly had a larger proportion of participants who were non-drinkers as compared to the urban elderly ( $p=0.002$ in men; $p=0.001$ in the total), but not women. The proportion of underweight was higher in rural elderly than urban elderly ( $p=0.040$ in the total).

Table 1. General characteristics of rural and urban Korean elderly.

\begin{tabular}{|c|c|c|c|c|c|c|c|c|c|c|}
\hline & & \multicolumn{3}{|c|}{ Men $(n=2271)$} & \multicolumn{3}{|c|}{ Women $(n=3021)$} & \multicolumn{3}{|c|}{ Total $(n=5292)$} \\
\hline & & $\begin{array}{c}\text { Urban } \\
(n=1627)\end{array}$ & $\begin{array}{c}\text { Rural } \\
(n=644)\end{array}$ & $p$ Value & $\begin{array}{c}\text { Urban } \\
(n=2160)\end{array}$ & $\begin{array}{c}\text { Rural } \\
(n=861)\end{array}$ & $p$ Value & $\begin{array}{c}\text { Urban } \\
(n=3787)\end{array}$ & $\begin{array}{c}\text { Rural } \\
(n=1505)\end{array}$ & $p$ Value \\
\hline \multirow[t]{3}{*}{ Age (year) } & & $72.0 \pm 0.1$ & $73.0 \pm 0.2$ & $<0.001$ & $72.6 \pm 0.1$ & $73.8 \pm 0.2$ & $<0.001$ & $72.4 \pm 0.1$ & $73.4 \pm 0.2$ & $<0.001$ \\
\hline & $65-74$ & 1055 (64.8) & $382(59.3)$ & 0.001 & $1351(62.5)$ & $449(52.2)$ & $<0.001$ & $2406(64.5)$ & $831(55.1)$ & $<0.001$ \\
\hline & $\geq 75$ & $572(35.2)$ & $262(40.7)$ & & $809(37.5)$ & $412(47.9)$ & & $1381(35.5)$ & $674(44.9)$ & \\
\hline \multirow[t]{3}{*}{ Education level (\%) } & $\leq$ Elementary & $583(35.7)$ & $309(47.2)$ & $<0.001$ & $1429(65.8)$ & $662(75.3)$ & $<0.001$ & $2012(52.4)$ & $971(63.0)$ & $<0.001$ \\
\hline & $\begin{array}{l}\leq \text { Middle } \\
\text { school }\end{array}$ & $254(15.5)$ & $115(17.3)$ & & $242(10.9)$ & $46(5.5)$ & & $496(12.9)$ & $161(10.6)$ & \\
\hline & $\begin{array}{l}\geq \text { High } \\
\text { school }\end{array}$ & $790(48.8)$ & $220(35.6)$ & & $489(23.3)$ & $153(19.2)$ & & 1279 (34.7) & $373(26.4)$ & \\
\hline \multirow[t]{4}{*}{ Income (\%) } & Low & $631(38.5)$ & $339(54.5)$ & $<0.001$ & $1073(48.8)$ & $547(65.3)$ & $<0.001$ & 1704 (44.2) & $886(60.6)$ & $<0.001$ \\
\hline & Middle-low & 487 (28.6) & $178(27.3)$ & & $559(25.2)$ & $184(20.3)$ & & $1046(26.7)$ & $362(23.3)$ & \\
\hline & Middle-high & $282(18.7)$ & $86(12.7)$ & & $301(15.5)$ & $74(8.9)$ & & $583(16.9)$ & $160(10.6)$ & \\
\hline & High & $213(14.2)$ & $36(5.6)$ & & $212(10.6)$ & $45(5.5)$ & & $425(12.2)$ & $81(5.5)$ & \\
\hline \multirow[t]{2}{*}{ Marital status (\%) } & Married & 1409 (87.3) & $569(89.0)$ & 0.304 & $1025(46.3)$ & $417(45.2)$ & 0.655 & 2434 (64.6) & $986(64.3)$ & 0.909 \\
\hline & Others ${ }^{(1)}$ & $218(12.8)$ & 75 (11.0) & & 1135 (53.7) & $444(54.8)$ & & $1353(35.4)$ & $519(35.7)$ & \\
\hline \multirow[t]{4}{*}{ Alcohol intake (\%) } & Never & $547(34.8)$ & $241(38.7)$ & 0.002 & $1363(63.8)$ & $579(69.3)$ & 0.072 & $1910(50.9)$ & $820(56.0)$ & 0.001 \\
\hline & $\leq 1 /$ month & $263(15.9)$ & $96(16.1)$ & & $524(25.2)$ & $177(20.7)$ & & $787(21.1)$ & $273(18.7)$ & \\
\hline & 2-4/month & $303(19.0)$ & $81(11.6)$ & & $133(6.3)$ & $47(5.6)$ & & $436(11.9)$ & $128(8.1)$ & \\
\hline & $\geq 2 /$ week & $476(30.4)$ & $207(33.7)$ & & $97(4.7)$ & $36(4.5)$ & & $573(16.1)$ & $243(17.2)$ & \\
\hline \multirow[t]{2}{*}{ Smoking status (\%) } & Past/never & $1229(79.8)$ & $482(81.1)$ & 0.560 & $1950(97.2)$ & 747 (95.5) & 0.191 & 3179 (89.4) & $1229(89.1)$ & 0.852 \\
\hline & Current & $301(20.2)$ & $111(18.9)$ & & $54(2.9)$ & $25(4.5)$ & & $355(10.6)$ & $136(10.9)$ & \\
\hline \multirow[t]{2}{*}{$\begin{array}{c}\text { Nutrition education } \\
(\%)\end{array}$} & Yes & $72(4.2)$ & $31(3.9)$ & 0.788 & $121(5.9)$ & $54(6.1)$ & 0.808 & $193(5.1)$ & $85(5.2)$ & 0.964 \\
\hline & No & 1551 (95.8) & $613(96.1)$ & & $2032(94.1)$ & $804(93.9)$ & & $3583(94.9)$ & 1417 (94.8) & \\
\hline \multirow[t]{4}{*}{$\begin{array}{l}\text { Body mass index } \\
\left(\mathrm{kg} / \mathrm{m}^{2}\right)\end{array}$} & & $23.6 \pm 0.1$ & $23.4 \pm 0.1$ & 0.151 & $24.4 \pm 0.1$ & $24.2 \pm 0.2$ & 0.251 & $24.0 \pm 0.1$ & $23.8 \pm 0.1$ & 0.125 \\
\hline & $<23$ & $692(41.2)$ & $292(46.4)$ & 0.063 & $740(34.0)$ & $321(36.7)$ & 0.311 & $1432(37.2)$ & $613(40.9)$ & 0.040 \\
\hline & $23 \sim<25$ & $443(28.3)$ & $153(23.9)$ & & $549(25.9)$ & $203(22.9)$ & & $992(26.9)$ & $356(23.3)$ & \\
\hline & $\geq 25$ & $492(30.5)$ & $199(29.7)$ & & $871(40.1)$ & 337 (40.5) & & $1363(35.8)$ & $536(35.8)$ & \\
\hline
\end{tabular}

Data represent mean \pm standard error or number of case (\%). Categorical variables were analyzed using the Chi-square test. Continuing variables were analyzed using the general linear model. Total data was additionally adjusted for sex using Chi-square test for categorical variables and general linear model for continuous variables.

(1) Widowed, separated, divorced, or never married.

Table 2 shows the participants' blood pressure and blood profiles. The blood triglyceride level was significantly higher in rural elderly than in urban elderly $(p=0.022$ in women; $p=0.026$ in the total), but not men. However, HDL-cholesterol level was significantly lower in rural elderly than in urban elderly only in women $(p=0.023)$.

Table 3 shows the participants' daily nutrient intake. The total daily energy intakes of total participants were $1665.4 \mathrm{kcal}$ for urban participants and $1688.0 \mathrm{kcal}$ for rural participants. The energy intake of the rural elderly was significantly higher than that of the urban elderly ( $p=0.002$ in men; $p=0.001$ in the total), but not among women. With respect to the distribution of energy intake of macronutrients, the rural elderly had a significantly higher carbohydrate intake $(p<0.001$ in men, in women and in the total) and lower protein intake $(p=0.002$ in women and in the total) and fat intake $(p<0.001$ in men, in women and in the total) than the urban elderly; however, the proportion of protein intake of men had no significant difference between urban and rural elderly. The intake and nutritional density of the minerals of study showed significant difference among the urban and rural participants; 
calcium ( $p=0.001$ and $p<0.001$ in men; $p=0.045$ and $p=0.035$ in women; $p=0.001$ for both intake and nutritional density in the total), phosphorus ( $p=0.010$ and $p=0.002$ in men; $p<0.001$ for both intake and nutritional density in women and in the total), and potassium ( $p=0.043$ and $p=0.035$ in men; $p=0.034$ and $p=0.007$ in women; $p=0.010$ and $p=0.003$ in the total) with rural elderly consumption being significantly lower than those of the urban elderly. Animal calcium intake $(p=0.017$ in men; $p=0.005$ in the total) and the percentage of animal calcium intake $(p=0.008$ in women and in the total) in the rural elderly were also significantly lower than those in the urban elderly. The calcium to phosphorus ratios in the rural elderly men were significantly lower than those in the urban elderly men $(p=0.015)$.

Table 2. Blood pressure and blood profiles of rural and urban Korean elderly.

\begin{tabular}{|c|c|c|c|c|c|c|c|c|c|}
\hline & \multicolumn{3}{|c|}{ Men $(n=2271)$} & \multicolumn{3}{|c|}{ Women $(n=3021)$} & \multicolumn{3}{|c|}{ Total $(n=5292)$} \\
\hline & $\begin{array}{c}\text { Urban } \\
(n=1627)\end{array}$ & $\begin{array}{c}\text { Rural } \\
(n=644)\end{array}$ & $p$ Value & $\begin{array}{c}\text { Urban } \\
(n=2160)\end{array}$ & $\begin{array}{c}\text { Rural } \\
(n=861)\end{array}$ & $p$ Value & $\begin{array}{c}\text { Urban } \\
(n=3787)\end{array}$ & $\begin{array}{c}\text { Rural } \\
(n=1505)\end{array}$ & $p$ Value \\
\hline $\begin{array}{l}\text { Systolic blood pressure } \\
(\mathrm{mmHg})\end{array}$ & $127.0 \pm 0.5$ & $125.4 \pm 0.9$ & 0.090 & $129.8 \pm 0.5$ & $129.2 \pm 0.8$ & 0.153 & $128.6 \pm 0.2$ & $127.5 \pm 0.7$ & 0.051 \\
\hline $\begin{array}{l}\text { Diastolic blood pressure } \\
(\mathrm{mmHg})\end{array}$ & $72.3 \pm 0.3$ & $70.8 \pm 0.6$ & 0.276 & $72.0 \pm 0.3$ & $71.6 \pm 0.4$ & 0.927 & $72.2 \pm 0.2$ & $71.3 \pm 0.4$ & 0.448 \\
\hline $\begin{array}{l}\text { Fasting blood glucose } \\
(\mathrm{mg} / \mathrm{dL})\end{array}$ & $109.1 \pm 0.9$ & $106.7 \pm 1.2$ & 0.200 & $106.4 \pm 0.6$ & $105.6 \pm 1.4$ & 0.731 & $107.7 \pm 0.5$ & $106.1 \pm 0.9$ & 0.255 \\
\hline Hemoglobin (mg/dL) & $14.5 \pm 0.1$ & $14.5 \pm 0.1$ & 0.385 & $13.1 \pm 0.1$ & $13.0 \pm 0.1$ & 0.450 & $13.7 \pm 0.1$ & $13.7 \pm 0.1$ & 0.996 \\
\hline Triglyceride (mg/dL) & $134.4 \pm 2.5$ & $139.0 \pm 3.9$ & 0.394 & $135.6 \pm 1.9$ & $149.0 \pm 5.2$ & 0.022 & $135.0 \pm 1.6$ & $144.4 \pm 3.5$ & 0.026 \\
\hline $\begin{array}{l}\text { Total cholesterol } \\
(\mathrm{mg} / \mathrm{dL})\end{array}$ & $179.3 \pm 1.1$ & $178.2 \pm 1.8$ & 0.611 & $192.0 \pm 1.0$ & $194.2 \pm 1.7$ & 0.276 & $186.1 \pm 0.8$ & $186.9 \pm 1.3$ & 0.646 \\
\hline $\begin{array}{l}\text { HDL-cholesterol } \\
\text { (mg/dL) }\end{array}$ & $46.4 \pm 0.4$ & $46.2 \pm 0.5$ & 0.913 & $49.9 \pm 0.3$ & $48.2 \pm 0.5$ & 0.023 & $48.3 \pm 0.3$ & $47.3 \pm 0.4$ & 0.082 \\
\hline $\begin{array}{l}\text { LDL-cholesterol } \\
\text { (mg/dL) }\end{array}$ & $198.8 \pm 1.3$ & $196.6 \pm 2.2$ & 0.450 & $214.8 \pm 1.2$ & $212.6 \pm 2.0$ & 0.481 & $207.4 \pm 0.9$ & $205.3 \pm 1.5$ & 0.308 \\
\hline
\end{tabular}

Data represent mean \pm standard error. Continuous variables were analyzed using the general linear model after adjusting for age, household income level, education level, and total energy intake. Total data was additionally adjusted for sex using general linear model.

Table 3. Daily energy, macronutrient, and mineral intake levels of rural and urban Korean elderly.

\begin{tabular}{|c|c|c|c|c|c|c|c|c|c|c|}
\hline & & \multicolumn{3}{|c|}{ Men $(n=2271)$} & \multicolumn{3}{|c|}{ Women $(n=3021)$} & \multicolumn{3}{|c|}{ Total $(n=5292)$} \\
\hline & & $\begin{array}{c}\text { Urban } \\
(n=1627)\end{array}$ & $\begin{array}{c}\text { Rural } \\
(n=644)\end{array}$ & $p$ Value & $\begin{array}{c}\text { Urban } \\
(n=2160)\end{array}$ & $\begin{array}{c}\text { Rural } \\
(n=861)\end{array}$ & $p$ Value & $\begin{array}{c}\text { Urban } \\
(n=3787)\end{array}$ & $\begin{array}{c}\text { Rural } \\
(n=1505)\end{array}$ & $p$ Value \\
\hline \multicolumn{2}{|c|}{ Energy (kcal) } & $1919.5 \pm 19.4$ & $1971.8 \pm 30.9$ & 0.002 & $1460.7 \pm 14.4$ & $1468.2 \pm 23.8$ & 0.057 & $1665.4 \pm 13.2$ & $1688.0 \pm 23.0$ & 0.001 \\
\hline \multirow{3}{*}{ Energy distribution } & $\begin{array}{c}\% \\
\text { Carbohydrate }\end{array}$ & $71.5 \pm 0.3$ & $73.9 \pm 0.4$ & $<0.001$ & $73.9 \pm 0.3$ & $77.3 \pm 0.4$ & $<0.001$ & $72.8 \pm 0.2$ & $75.8 \pm 0.4$ & $<0.001$ \\
\hline & $\%$ Protein & $13.8 \pm 0.1$ & $13.4 \pm 0.2$ & 0.158 & $12.8 \pm 0.1$ & $12.1 \pm 0.2$ & 0.002 & $13.2 \pm 0.1$ & $12.6 \pm 0.1$ & 0.002 \\
\hline & $\%$ Fat & $14.7 \pm 0.2$ & $12.8 \pm 0.3$ & $<0.001$ & $13.3 \pm 0.2$ & $10.7 \pm 0.3$ & $<0.001$ & $13.9 \pm 0.2$ & $11.6 \pm 0.3$ & $<0.001$ \\
\hline \multicolumn{2}{|c|}{ Calcium $(\mathrm{mg})$} & $469.0 \pm 10.1$ & $421.8 \pm 12.6$ & 0.001 & $361.9 \pm 6.1$ & $330.4 \pm 10.1$ & 0.045 & $409.7 \pm 6.1$ & $370.3 \pm 9.1$ & 0.001 \\
\hline \multicolumn{2}{|c|}{ Calcium $(\mathrm{mg} / 1000 \mathrm{kcal})$} & $247.0 \pm 4.0$ & $216.9 \pm 5.1$ & $<0.001$ & $249.5 \pm 3.5$ & $226.3 \pm 6.2$ & 0.035 & $248.3 \pm 2.8$ & $222.2 \pm 4.8$ & 0.001 \\
\hline \multicolumn{2}{|c|}{ Animal calcium (mg) } & $151.4 \pm 7.6$ & $120.7 \pm 8.0$ & 0.017 & $121.1 \pm 4.4$ & $99.3 \pm 6.7$ & 0.081 & $134.6 \pm 4.3$ & $108.7 \pm 5.6$ & 0.005 \\
\hline \multicolumn{2}{|c|}{ Animal calcium (\%) } & $26.5 \pm 0.6$ & $24.0 \pm 0.9$ & 0.265 & $26.9 \pm 0.6$ & $22.9 \pm 0.9$ & 0.008 & $26.7 \pm 0.4$ & $23.4 \pm 0.7$ & 0.008 \\
\hline \multicolumn{2}{|c|}{ Phosphorus (mg) } & $1018.6 \pm 13.5$ & $977.8 \pm 21.1$ & 0.010 & $774.7 \pm 9.5$ & $715.1 \pm 15.9$ & $<0.001$ & $883.6 \pm 9.2$ & $829.8 \pm 15.2$ & $<0.001$ \\
\hline \multicolumn{2}{|c|}{ Phosphorus (mg/1000 kcal) } & $532.9 \pm 4.1$ & $496.2 \pm 6.3$ & 0.002 & $530.4 \pm 3.6$ & $485.7 \pm 6.6$ & $<0.001$ & $531.5 \pm 3.0$ & $490.2 \pm 5.5$ & $<0.001$ \\
\hline \multicolumn{2}{|c|}{ Calcium: Phosphorus ratio } & $0.45: 1$ & $0.43: 1$ & 0.015 & $0.46: 1$ & $0.46: 1$ & 0.873 & $0.46: 1$ & $0.45: 1$ & 0.177 \\
\hline \multicolumn{2}{|c|}{ Sodium (mg) } & $3736.4 \pm 69.2$ & $\begin{array}{c}3740.5 \pm \\
119.0\end{array}$ & 0.723 & $2625.3 \pm 45.2$ & $2686.7 \pm 97.2$ & 0.502 & $3121.0 \pm 44.0$ & $3146.8 \pm 86.8$ & 0.816 \\
\hline \multicolumn{2}{|c|}{ Sodium (mg/1000 kcal) } & $1969.6 \pm 32.5$ & $1929.9 \pm 50.5$ & 0.863 & $1809.8 \pm 26.6$ & $1848.0 \pm 59.6$ & 0.570 & $1881.1 \pm 21.4$ & $1883.7 \pm 45.1$ & 0.738 \\
\hline \multicolumn{2}{|c|}{ Potassium (mg) } & $3013.1 \pm 45.5$ & $2876.6 \pm 72.1$ & 0.043 & $2435.2 \pm 35.6$ & $2243.8 \pm 60.7$ & 0.034 & $2693.1 \pm 32.3$ & $2520.1 \pm 56.4$ & 0.010 \\
\hline \multicolumn{2}{|c|}{ Potassium (mg/1000 kcal) } & $1577.5 \pm 15.7$ & $1467.4 \pm 26.9$ & 0.035 & $1677.8 \pm 18.7$ & $1521.7 \pm 32.1$ & 0.007 & $1633.0 \pm 13.6$ & $1498.0 \pm 25.8$ & 0.003 \\
\hline
\end{tabular}

Data represent mean \pm standard error. $p$ values were calculated by general linear model after adjusting for age, household income level, education level, and total energy intake. Total data was additionally adjusted for sex using general linear model.

Table 4 shows the mineral intake levels. The proportions of RNI and below EAR for calcium $(p=0.001$ and $p=0.003$ in men; $p=0.045$ and $p=0.033$ in women; $p=0.001$ for both RNI and EAR in the total) and phosphorus ( $p=0.010$ and $p=0.021$ in men; $p<0.001$ and $p=0.001$ in women; $p<0.001$ and $p=0.001$ in the total) were significantly lower in the rural elderly than in the urban elderly. Insufficient 
consumptions less than $75 \%$ of RNI of calcium ( $p=0.011$ in men and in the total) and of phosphorus ( $p<0.001$ in women; $p=0.001$ in the total) were higher in the rural elderly than in the urban elderly. In particular, the proportion of below EAR of calcium was above $80 \%$, and the intake levels of calcium were under $55 \%$ of RNI in the total population and only $41.3 \%$ and $45.2 \%$ of RNI in the rural and urban elderly women, respectively. The proportion of AI for potassium was significantly lower $(p=0.043$ in men; $p=0.034$ in women; $p=0.010$ in the total) and insufficient consumption less than $75 \%$ of AI of potassium was higher in the rural elderly than in the urban elderly $(p=0.029$ in men; $p=0.001$ in women; $p<0.001$ in the total). In particular, in the elderly women, the potassium intake was $64.1 \%$ of $\mathrm{AI}$ in the rural and $69.6 \%$ of $\mathrm{AI}$ in the urban.

Table 4. Mineral intake levels by Dietary Reference Intakes (DRI) of rural and urban Korean elderly.

\begin{tabular}{|c|c|c|c|c|c|c|c|c|c|c|}
\hline & & \multicolumn{3}{|c|}{ Men $(n=2271)$} & \multicolumn{3}{|c|}{ Women $(n=3021)$} & \multicolumn{3}{|c|}{ Total $(n=5292)$} \\
\hline & & $\begin{array}{c}\text { Urban } \\
(n=1627)\end{array}$ & $\begin{array}{c}\text { Rural } \\
(n=644)\end{array}$ & $p$ Value & $\begin{array}{c}\text { Urban } \\
(n=2160)\end{array}$ & $\begin{array}{c}\text { Rural } \\
(n=861)\end{array}$ & $p$ Value & $\begin{array}{c}\text { Urban } \\
(n=3787)\end{array}$ & $\begin{array}{c}\text { Rural } \\
(n=1505)\end{array}$ & $p$ Value \\
\hline \multirow[t]{5}{*}{ Calcium } & RNI (\%) & $67.0 \pm 1.5$ & $60.3 \pm 1.8$ & 0.001 & $45.2 \pm 0.8$ & $41.3 \pm 1.3$ & 0.045 & $54.9 \pm 0.8$ & $49.6 \pm 1.2$ & 0.001 \\
\hline & $<75 \%$ RNI & 1098 (68.1) & 489 (75.8) & 0.011 & 1901 (87.5) & 778 (89.2) & 0.511 & 2999 (78.9) & 1267 (83.4) & 0.011 \\
\hline & $\begin{array}{c}75-125 \% \\
\text { RNI }\end{array}$ & $420(25.8)$ & $125(19.2)$ & & $219(10.7)$ & $67(8.9)$ & & $639(17.4)$ & $192(13.4)$ & \\
\hline & $>125 \%$ RNI & $109(6.1)$ & $30(5.0)$ & & $40(1.8)$ & $16(1.9)$ & & $149(3.8)$ & $46(3.2)$ & \\
\hline & $<$ EAR & $1199(74.3)$ & $522(81.4)$ & 0.003 & $1829(84.2)$ & $769(88.1)$ & 0.033 & $3028(79.8)$ & $1291(85.2)$ & 0.001 \\
\hline \multirow[t]{5}{*}{ Phosphorus } & RNI (\%) & $145.5 \pm 1.9$ & $139.7 \pm 3.0$ & 0.010 & $110.7 \pm 1.4$ & $102.2 \pm 2.3$ & $<0.001$ & $126.2 \pm 1.3$ & $118.5 \pm 2.2$ & $<0.001$ \\
\hline & $<75 \%$ RNI & $126(8.0)$ & $68(9.2)$ & 0.264 & $550(25.3)$ & $280(34.0)$ & $<0.001$ & $676(17.6)$ & 348 (23.2) & 0.001 \\
\hline & $\begin{array}{c}75-125 \% \\
\text { RNI }\end{array}$ & $566(35.3)$ & $238(38.5)$ & & $907(42.3)$ & $361(40.7)$ & & $1473(39.1)$ & $599(39.8)$ & \\
\hline & $>125 \%$ RNI & $935(56.7)$ & $338(52.3)$ & & $703(32.5)$ & $220(25.3)$ & & $1638(43.3)$ & $558(37.1)$ & \\
\hline & $<$ EAR & 190 (11.8) & 109 (16.2) & 0.021 & 714 (33.1) & 343 (40.8) & 0.001 & $904(23.6)$ & $452(30.1)$ & 0.001 \\
\hline \multirow[t]{2}{*}{ Sodium } & GI (\%) & $186.8 \pm 3.5$ & $187.0 \pm 6.0$ & 0.723 & $131.3 \pm 2.3$ & $134.3 \pm 4.9$ & 0.502 & $156.1 \pm 2.2$ & $157.3 \pm 4.3$ & 0.816 \\
\hline & $>\mathrm{GI}$ & $1297(79.6)$ & $508(79.07)$ & 0.789 & $1236(56.9)$ & 483 (54.3) & 0.285 & $2533(67.1)$ & 991 (65.1) & 0.322 \\
\hline \multirow[t]{4}{*}{ Potassium } & $\mathrm{AI}(\%)$ & $86.1 \pm 1.3$ & $82.2 \pm 2.1$ & 0.043 & $69.6 \pm 1.0$ & $64.1 \pm 1.7$ & 0.034 & $76.9 \pm 0.9$ & $72.0 \pm 1.6$ & 0.010 \\
\hline & $<75 \% \mathrm{AI}$ & $726(46.7)$ & $336(53.3)$ & 0.029 & 1387 (63.9) & 625 (72.5) & 0.001 & $2110(56.2)$ & $961(64.1)$ & $<0.001$ \\
\hline & $75-125 \%$ AI & $643(37.9)$ & 214 (31.5) & & 623 (29.2) & 179 (21.1) & & $1266(33.1)$ & 393 (25.7) & \\
\hline & $>125 \% \mathrm{AI}$ & 258 (15.4) & 94 (15.2) & & $153(6.9)$ & $57(6.4)$ & & 411 (10.7) & $151(25.7)$ & \\
\hline
\end{tabular}

RNI, recommended nutrient intake; EAR, estimated average requirement; AI, adequate intake; GI, goal intake (2000 $\mathrm{mg}$ /day). Data represent mean \pm standard error or number of case (\%). Categorical variables were analyzed using the Chi-square test. Continuing variables were analyzed using the general linear model after adjusting for age, household income level, education level, and total energy intake. Total data was additionally adjusted for sex using Chi-square test for categorical variables and general linear model for continuous variables.

Table 5 shows the main food sources of minerals. The food sources that provided the most calcium, in descending order, were Chinese cabbage kimchi, milk, and anchovy in Korean rural and urban elderly. The food item that contributed the most to daily calcium intake was Chinese cabbage kimchi for both rural (11.5\%) and urban (9.6\%) Korean elderly. However, there was difference in the food item that provided the most calcium for the Korean elderly women: Chinese cabbage kimchi (10.1\%), rural; milk (11.2\%), urban. The percentage of calcium intake that was derived from milk was lower in the Korean rural elderly $(6.3 \%)$ than in the Korean urban elderly $(9.2 \%)$. The food sources that provided the most phosphorus were white rice $(22.3 \%)$, soybean $(4.1 \%)$, and Chinese cabbage kimchi (3.1\%) for the Korean rural elderly and white rice $(17.1 \%)$, soybean $(4.6 \%)$, and milk (3.7\%) for the Korean urban elderly. The food sources that provided the most potassium were white rice (14.2\%), Chinese cabbage kimchi $(5.1 \%)$, and oriental melon $(4.5 \%)$ for the Korean rural elderly and white rice $(10.8 \%)$, Chinese cabbage kimchi $(4.4 \%)$, and sweet potato $(3.7 \%)$ for the Korean urban elderly. The food item that contributed the most to daily intake of phosphorus and potassium was white rice. The percentages of phosphorus and potassium intake that were derived from white rice were higher in Korean rural participants than in Korean urban participants. The food sources that provided the most sodium were salt $(17.3 \%)$, doenjang $(14.1 \%)$, and Chinese cabbage kimchi $(13.1 \%)$ for the Korean rural elderly and salt $(17.9 \%)$, Chinese cabbage kimchi $(12.3 \%)$, and doenjang $(12.3 \%)$ for the Korean urban elderly. 
Table 5. Main food sources of minerals of rural and urban Korean elderly.

\begin{tabular}{|c|c|c|c|c|c|c|c|c|c|c|c|c|c|c|c|c|c|c|c|}
\hline \multirow[b]{3}{*}{ Minerals } & \multirow[b]{3}{*}{ Rank } & \multicolumn{6}{|c|}{ Men $(n=2271)$} & \multicolumn{6}{|c|}{ Women $(n=3021)$} & \multicolumn{6}{|c|}{ Total $(n=5292)$} \\
\hline & & \multicolumn{3}{|c|}{ Urban $(n=1627)$} & \multicolumn{3}{|c|}{ Rural $(n=644)$} & \multicolumn{3}{|c|}{ Urban $(n=2160)$} & \multicolumn{3}{|c|}{ Rural $(n=861)$} & \multicolumn{3}{|c|}{ Urban $(n=3787)$} & \multicolumn{3}{|c|}{ Rural $(n=1505)$} \\
\hline & & Food name & $\%$ & Cum $\%$ & Food name & $\%$ & Cum $\%$ & Food name & $\%$ & Cum $\%$ & Food name & $\%$ & Cum $\%$ & Food name & $\%$ & Cum $\%$ & Food name & $\%$ & Cum $\%$ \\
\hline \multirow[t]{10}{*}{ Calcium } & 1 & Kimchi $^{(1)}$ & 10.6 & 10.6 & Kimchi $^{(1)}$ & 13.0 & 13.0 & Milk & 11.2 & 11.2 & Kimchi $^{(1)}$ & 10.1 & 10.1 & Kimchi $^{(1)}$ & 9.6 & 9.6 & Kimchi $^{(1)}$ & 11.5 & 11.5 \\
\hline & 2 & Milk & 7.3 & 17.9 & Milk & 5.5 & 18.5 & Kimchi $^{(1)}$ & 8.5 & 19.7 & Milk & 7.2 & 17.3 & Milk & 9.2 & 18.8 & Milk & 6.3 & 17.8 \\
\hline & 3 & Anchovy & 6.4 & 24.4 & Anchovy & 4.9 & 23.4 & Anchovy & 5.2 & 24.9 & Anchovy & 5.5 & 22.7 & Anchovy & 5.8 & 24.7 & Anchovy & 5.2 & 23.0 \\
\hline & 4 & Soybean & 3.7 & 28.1 & White rice & 3.9 & 27.3 & Soybean & 3.5 & 28.5 & White rice & 4.3 & 27.0 & Soybean & 3.6 & 28.3 & White rice & 4.1 & 27.1 \\
\hline & 5 & Pond loach & 3.2 & 31.3 & Soybean & 3.5 & 30.8 & White rice & 3.1 & 31.5 & Soybean & 3.1 & 30.1 & White rice & 3.0 & 31.3 & Soybean & 3.3 & 30.4 \\
\hline & 6 & White rice & 2.9 & 34.2 & Pond loach & 2.7 & 33.4 & $\begin{array}{c}\text { Yoghurt, Liquid } \\
\text { type }\end{array}$ & 3.0 & 34.5 & $\begin{array}{c}\text { Yoghurt, Liquid } \\
\text { type }\end{array}$ & 2.6 & 32.7 & Sea mustard & 2.7 & 34.0 & Welsh onion & 2.4 & 32.9 \\
\hline & 7 & Sea mustard & 2.8 & 37.0 & Welsh onion & 2.5 & 35.9 & Sea mustard & 2.7 & 37.2 & Welsh onion & 2.4 & 35.1 & Pond loach & 2.6 & 36.6 & Sea mustard & 2.2 & 35.1 \\
\hline & 8 & Tofu & 2.3 & 39.3 & Tofu & 2.1 & 38.1 & Egg & 2.0 & 39.2 & Sea mustard & 2.3 & 37.4 & $\begin{array}{c}\text { Yoghurt, Liquid } \\
\text { type }\end{array}$ & 2.4 & 39.0 & $\begin{array}{c}\text { Yoghurt, Liquid } \\
\text { type }\end{array}$ & 2.1 & 37.2 \\
\hline & 9 & Welsh onion & 2.2 & 41.5 & Coffee & 2.1 & 40.2 & Pond loach & 2.0 & 41.1 & Crab & 2.1 & 39.5 & Tofu & 2.1 & 41.1 & Pond loach & 2.0 & 39.1 \\
\hline & 10 & Egg & 2.0 & 43.5 & Sea mustard & 2.1 & 42.2 & Tofu & 1.9 & 43.0 & Doenjang & 2.1 & 41.7 & Welsh onion & 2.0 & 43.1 & Doenjang & 2.0 & 41.1 \\
\hline \multirow[t]{10}{*}{ Phosphorus } & 1 & White rice & 16.5 & 16.5 & White rice & 21.0 & 21.0 & White rice & 17.9 & 17.8 & White rice & 23.7 & 23.7 & White rice & 17.1 & 17.1 & White rice & 22.3 & 22.3 \\
\hline & 2 & Soybean & 4.7 & 21.2 & Soybean & 4.2 & 25.2 & Soybean & 4.6 & 22.4 & Soybean & 3.9 & 27.6 & Soybean & 4.6 & 21.8 & Soybean & 4.1 & 26.4 \\
\hline & 3 & Egg & 3.2 & 24.5 & Kimchi $^{(1)}$ & 3.4 & 28.6 & Milk & 4.4 & 26.8 & Kimchi ${ }^{(1)}$ & 2.8 & 30.4 & Milk & 3.7 & 25.5 & Kimchi $^{(1)}$ & 3.1 & 29.5 \\
\hline & 4 & Glutinous rice & 3.0 & 27.5 & Pork & 3.2 & 31.9 & Glutinous rice & 3.6 & 30.4 & Brown rice & 2.7 & 33.1 & Glutinous rice & 3.3 & 28.8 & Brown rice & 2.7 & 32.2 \\
\hline & 5 & Brown rice & 3.0 & 30.5 & Egg & 2.7 & 34.6 & Brown rice & 3.3 & 33.6 & Milk & 2.4 & 35.5 & Egg & 3.2 & 32.0 & Pork & 2.6 & 34.8 \\
\hline & 6 & Kimchi $^{(1)}$ & 3.0 & 33.5 & Brown rice & 2.7 & 37.3 & Egg & 3.2 & 36.8 & Egg & 2.4 & 37.9 & Brown rice & 3.1 & 35.1 & Egg & 2.5 & 37.4 \\
\hline & 7 & Milk & 3.0 & 36.4 & Tofu & 2.6 & 39.9 & Beef & 2.5 & 39.3 & Anchovy & 2.3 & 40.2 & Kimchi $^{(1)}$ & 2.7 & 37.8 & Tofu & 2.3 & 39.7 \\
\hline & 8 & Tofu & 2.9 & 39.3 & Coffee & 2.5 & 42.5 & Tofu & 2.4 & 41.7 & Glutinous rice & 2.3 & 42.5 & Tofu & 2.7 & 40.5 & Glutinous rice & 2.3 & 42.0 \\
\hline & 9 & Pork & 2.9 & 42.2 & Beef & 2.4 & 44.9 & Kimchi $^{(1)}$ & 2.4 & 44.1 & Beef & 2.1 & 44.6 & Beef & 2.6 & 43.1 & Beef & 2.2 & 44.2 \\
\hline & 10 & Anchovy & 2.9 & 45.0 & Glutinous rice & 2.3 & 47.1 & Anchovy & 2.3 & 46.4 & Tofu & 2.0 & 46.6 & Anchovy & 2.6 & 45.7 & Milk & 2.2 & 46.4 \\
\hline \multirow[t]{7}{*}{ Sodium } & 1 & Salt & 18.4 & 18.4 & Salt & 18.3 & 18.3 & Salt & 17.3 & 17.3 & Salt & 16.2 & 16.2 & Salt & 17.9 & 17.9 & Salt & 17.3 & 17.3 \\
\hline & 2 & Kimchi $^{(1)}$ & 13.2 & 31.6 & Kimchi $^{(1)}$ & 14.3 & 32.5 & Doenjang & 13.7 & 31.0 & Doenjang & 15.8 & 32.1 & Kimchi $^{(1)}$ & 12.3 & 30.2 & Doenjang & 14.1 & 31.4 \\
\hline & 3 & Doenjang & 10.9 & 42.6 & Doenjang & 12.5 & 45.0 & Kimchi $^{(1)}$ & 11.3 & 42.3 & Kimchi $^{(1)}$ & 12.0 & 44.0 & Doenjang & 12.3 & 42.4 & Kimchi $^{(1)}$ & 13.1 & 44.5 \\
\hline & 4 & Soy sauce & 10.6 & 53.2 & Soy sauce & 10.3 & 55.3 & Soy sauce & 10.5 & 52.9 & Soy sauce & 10.6 & 54.6 & Soy sauce & 10.6 & 53.0 & Soy sauce & 10.4 & 55.0 \\
\hline & 5 & $\begin{array}{c}\text { Fermented red } \\
\text { pepper paste }\end{array}$ & 3.6 & 56.8 & Noodle & 4.2 & 59.5 & Noodle & 3.4 & 56.2 & Noodle & 4.0 & 58.6 & Noodle & 3.3 & 56.4 & Noodle & 4.1 & 59.1 \\
\hline & 6 & Noodle & 3.3 & 60.1 & Ramyeon & 3.6 & 63.1 & $\begin{array}{c}\text { Fermented red } \\
\text { pepper paste }\end{array}$ & 2.6 & 58.8 & $\begin{array}{l}\text { Fermented red } \\
\text { pepper paste }\end{array}$ & 2.6 & 61.2 & $\begin{array}{l}\text { Fermented red } \\
\text { pepper paste }\end{array}$ & 3.1 & 59.5 & $\begin{array}{c}\text { Fermented red } \\
\text { pepper paste }\end{array}$ & 3.0 & 62.0 \\
\hline & 7 & Ramyeon & 3.0 & 63.0 & $\begin{array}{l}\text { Fermented red } \\
\text { pepper paste }\end{array}$ & 3.3 & 66.4 & Ramyeon & 2.3 & 61.1 & $\begin{array}{c}\text { Kimchi, } \\
\text { Dongchimi }\end{array}$ & 2.5 & 63.7 & Ramyeon & 2.6 & 62.1 & Ramyeon & 2.6 & 64.6 \\
\hline
\end{tabular}


Table 5. Cont.

\begin{tabular}{|c|c|c|c|c|c|c|c|c|c|c|c|c|c|c|c|c|c|c|c|}
\hline & \multirow[b]{3}{*}{8} & \multicolumn{6}{|c|}{ Men $(n=2271)$} & \multicolumn{6}{|c|}{ Women $(n=3021)$} & \multicolumn{6}{|c|}{ Total $(n=5292)$} \\
\hline & & \multicolumn{3}{|c|}{ Urban $(n=1627)$} & \multicolumn{3}{|c|}{ Rural $(n=644)$} & \multicolumn{3}{|c|}{ Urban $(n=2160)$} & \multicolumn{3}{|c|}{ Rural $(n=861)$} & \multicolumn{3}{|c|}{ Urban $(n=3787)$} & \multicolumn{3}{|c|}{ Rural $(n=1505)$} \\
\hline & & $\begin{array}{l}\text { Salt-fermented } \\
\text { seafood }\end{array}$ & 2.1 & 65.2 & $\begin{array}{l}\text { Salt-fermented } \\
\text { seafood }\end{array}$ & 3.0 & 69.4 & Sea mustard & 2.2 & 63.3 & Rice cake & 2.2 & 65.9 & Sea mustard & 2.1 & 64.2 & $\begin{array}{l}\text { Salt-fermented } \\
\text { seafood }\end{array}$ & 2.5 & 67.2 \\
\hline & 9 & Sea mustard & 2.1 & 67.3 & $\begin{array}{c}\text { Kimchi, } \\
\text { Dongchimi }\end{array}$ & 1.8 & 71.2 & Rice cake & 2.2 & 65.4 & $\begin{array}{c}\text { Kimchi, } \\
\text { Yeolmumulkimchi }\end{array}$ & 2.1 & 68.1 & $\begin{array}{l}\text { Salt-fermented } \\
\text { seafood }\end{array}$ & 2.0 & 66.2 & $\begin{array}{c}\text { Kimchi, } \\
\text { Nabakkimchi }\end{array}$ & 2.2 & 69.3 \\
\hline & 10 & $\begin{array}{c}\text { Kimchi, } \\
\text { Yeolmumulkimchi, }\end{array}$ & 1.5 & 68.8 & $\begin{array}{c}\text { Kimchi, } \\
\text { Yeolmumulkimchi } \\
\end{array}$ & 1.6 & 72.8 & $\begin{array}{c}\text { Kimchi, } \\
\text { Nabakkimchi }\end{array}$ & 2.1 & 67.6 & $\begin{array}{l}\text { Salt-fermented } \\
\text { seafood }\end{array}$ & 2.0 & 70.1 & $\begin{array}{c}\text { Kimchi, } \\
\text { Yeolmumulkimchi }\end{array}$ & 1.8 & 68.0 & $\begin{array}{l}\text { Kimchi, } \\
\text { Yeolmumulkimchi }\end{array}$ & 1.9 & 71.2 \\
\hline \multirow[t]{10}{*}{ Potassium } & 1 & White rice & 10.8 & 10.8 & White rice & 13.7 & 13.7 & White rice & 10.9 & 10.9 & White rice & 14.6 & 14.6 & White rice & 10.8 & 10.8 & White rice & 14.2 & 14.2 \\
\hline & 2 & Kimchi $^{(1)}$ & 5.1 & 15.9 & Kimchi $^{(1)}$ & 5.8 & 19.5 & Sweet potato & 4.3 & 15.2 & Oriental melon & 4.8 & 19.3 & Kimchi $^{(1)}$ & 4.4 & 15.3 & Kimchi $^{(1)}$ & 5.1 & 19.3 \\
\hline & 3 & Soybean & 3.7 & 19.5 & Oriental melon & 4.3 & 23.8 & Oriental melon & 4.1 & 19.2 & Kimchi $^{(1)}$ & 4.5 & 23.8 & Sweet potato & 3.7 & 19.0 & Oriental melon & 4.5 & 23.8 \\
\hline & 4 & Apple & 3.4 & 23.0 & Coffee & 3.4 & 27.3 & Kimchi $^{(1)}$ & 3.8 & 23.1 & $\begin{array}{l}\text { Potato } \\
\end{array}$ & 4.2 & 28.0 & Soybean & 3.5 & 22.5 & Potato & 3.7 & 27.5 \\
\hline & 5 & Sweet potato & 3.1 & 26.0 & Soybean & 3.2 & 30.5 & Apple & 3.4 & 26.5 & Sweet potato & 3.6 & 31.6 & Apple & 3.4 & 25.9 & Sweet potato & 3.2 & 30.7 \\
\hline & 6 & Coffee & 2.9 & 28.9 & Potato & 3.2 & 33.7 & Potato & 3.4 & 29.9 & Soybean & 2.9 & 34.5 & Oriental melon & 3.3 & 29.2 & Soybean & 3.1 & 33.7 \\
\hline & 7 & Radish & 2.9 & 31.8 & Radish & 2.9 & 36.5 & Soybean & 3.3 & 33.2 & Apple & 2.5 & 37.0 & Potato & 2.9 & 32.0 & Coffee & 2.8 & 36.6 \\
\hline & 8 & Oriental melon & 2.4 & 34.2 & Sweet potato & 2.7 & 39.2 & Radish & 2.6 & 35.8 & Radish & 2.3 & 39.3 & Radish & 2.7 & 34.7 & Radish & 2.6 & 39.1 \\
\hline & 9 & Potato & 2.3 & 36.5 & Hot pepper & 2.3 & 41.5 & Milk & 2.4 & 38.2 & Coffee & 2.3 & 41.6 & Coffee & 2.5 & 37.2 & Apple & 2.3 & 41.4 \\
\hline & 10 & Sea mustard & 2.3 & 38.8 & Apple & 2.0 & 43.5 & Coffee & 2.0 & 40.3 & Persimmon & 2.0 & 43.6 & Sea mustard & 2.1 & 39.3 & Hot pepper & 2.0 & 43.4 \\
\hline
\end{tabular}

$\%$; Percentages of total intake. Cum\%; Cumulative percentages of total intake. ${ }^{(1)}$ Kimchi, Chinese cabbage kimchi. 


\section{Discussion}

There are urban-rural differences in demographic characteristics, income level, and education level that possibly lead to disparities in food supplies and availability and accessibility of foods $[20,22,39,40]$. The food availability and accessibility may affect the individual's food choices and eating behaviors and are closely related to the quality of meals served and individual's nutritional status [41]. Food intake gradually declines with age $[5,7,8]$. Decreasing food intake of the elderly is related to the deterioration of nutrient intake, specifically insufficient intake of micronutrients. In addition, the nutrient intake of elderly between urban and rural areas displayed a different pattern. A previous study with 1239 Korean elderly aged 65 years and older found that the intake of iron, vitamin A, niacin, and vitamin C among the urban residing elderly was higher than that among the rural residing elderly [22]. Based on these previous findings, in this study, we assumed that there might be differences in mineral intake between the urban and rural elderly. Our results are consistent with the previous findings that the intake of calcium, phosphorus, and potassium was lower in the rural elderly than in the urban elderly and that the proportion of participants with mineral intake below the EAR was significantly higher in the rural elderly than in the urban elderly. Furthermore, primary food sources of calcium, phosphorus, sodium, and potassium were different between both groups.

The mean age of participants in this study was significantly higher in the rural elderly than in urban elderly. The proportion of population aged 65 and older of the total Korean population was $14.3 \%$, according to the 2018 survey [2]. However, the proportion of population aged 65 and older of the total farm household population was $44.7 \%$ in Korea, showing a continuous upward trend of population aging in rural areas [42]. Other previous studies also reported that the mean age in rural areas was significantly higher than that in urban areas $[23,25]$; this is probably due to the rapid industrialization and continued migration of young adults to the cities, resulting in the increased ratio of older adults in rural areas.

Education level is one of the most frequently used indicators of socioeconomic status and it is closely associated with other indicators of socioeconomic status [43]. Lower educational attainment might lead to lower income, which might influence food choice. Rural residents are more likely to have lower education level, a greater proportion of individuals with poverty level household income, and lower accessibility to supermarkets than urban residents [44]. A study reported that the rural elderly had poor access to grocery stores due to transportation difficulties as public transportation is lacking in rural settings [45]. Earlier studies on the urban and rural elderly have reported that both income and education levels of the rural elderly were significantly lower than those of the urban elderly $[10,15,20]$, which is consistent with our findings. Differences in the income and education levels between the urban and rural elderly in the present study were thought to affect food choice and food intake.

This study performed an analysis on the general health indicators in the urban and rural elderly and found significantly lower blood triglyceride levels in urban elderly than in rural elderly. In a study that was conducted in some regions of Indonesia [20], there was no significant difference in hemoglobin levels between urban and rural elderly, but the systolic blood pressure was significantly higher in the rural elderly population than in the urban elderly population. In the study conducted by Chun et al. [18], an analysis was conducted on the relationship between chronic diseases in Korean elderly and residential areas, classified into large cities, cities, and rural areas. In that study, the hypertension diagnosis rate showed no significant difference between the regions, whereas the diabetes diagnosis rate was significantly lower in rural areas. Another previous study reported that a high-carbohydrate diet in Korea was associated with increased triglycerides levels in blood [46]. The rural elderly in this study also showed significantly higher energy intake from carbohydrates than the urban elderly did, which we concluded have caused the high blood triglyceride levels in the rural elderly. Therefore, our findings suggest an urgent need for the development of education programs and measures to achieve recommended carbohydrate intakes in order to prevent dyslipidemia and coronary artery disease in the rural elderly. 
In this study, the energy intake ratio of carbohydrate, protein, and fat was $72.8 \%, 13.2 \%$, and $13.9 \%$ in the urban elderly and $75.8 \%, 12.6 \%$, and $11.6 \%$ in the rural elderly, respectively. A recommended ratio of carbohydrate, protein, and fat was $55 \sim 65 \%, 7 \sim 20 \%$, and $15 \sim 30 \%$, respectively, according to Acceptable Macronutrient Distribution Ranges in the 2015 DRI for Koreans (KDRIs) [38]. This study's carbohydrate intake ratio of participants was high when compared to those recommendations, while the protein and fat intake ratio was low. Rural men and women residents had significantly higher energy intake ratio of carbohydrate, but significantly lower energy intake ratio of fat than urban residents. Koreans have a traditional diet consisting of rice as staple food, soup, and side dishes, and, thus, carbohydrates account for a high percentage of Korean meals. Previous studies found that despite the Westernization of Korean diets, the rural elderly tend to maintain traditional Korean diets consisting of carbohydrate-rich foods than the urban elderly [25]. An excessive intake of carbohydrates has been reported as one of the major causes of exacerbation of glucose intolerance [47], and carbohydrate-dense diets are also known to be strongly associated with disorders of lipid metabolism [48]. Therefore, nutrition education on the risk of excessive carbohydrate intake and on the importance of dietary diversity is suggested for the rural elderly. Further research is required on the comprehensive analysis of foods and factors that contribute to carbohydrate intake.

Differences in urban-rural environments and socioeconomic factors may lead to differences in the types of food consumed between regions. According to a previous study, urban elderly residents consumed meats, eggs, fish, milk, fruit, and fast foods, including fatty foods, ice cream, cakes, snacks, and carbonated drinks, but the rural elderly residents consumed more vegetables than the urban elderly in Korea [25]. Such quantitative and qualitative differences in food intake between urban and rural settings eventually lead to disparities in nutrient intake.

In this study, the proportion of participants that were aged 65 and older that consumed calcium below the EAR was $76.0 \%$ in men, $85.2 \%$ in women, respectively, showing seriously inadequate calcium intake, which was more severe among elderly women (data not shown). The present study results showed that the intake of calcium, as one of the trace minerals, was remarkably different between the urban and rural elderly men and women, and the proportion of participants with calcium intake below the EAR was significantly higher in rural areas than in urban areas. As age increases, rapid bone loss occurs, which emphasizes the need for calcium nutrition in the elderly. In a previous study, the incidence rate of osteoporosis of postmenopausal women was significantly higher among rural residents than among urban residents [17]. The deficiency of calcium intake in the elderly has been continuously reported in Korea, and the low calcium intake is partly attributed to the relatively limited food sources of calcium [5]. The calcium intake ratio supplied by milk was $7.3 \%$ in the urban elderly men and $5.5 \%$ in the rural elderly men, according to the analysis of food sources of calcium in this study. The primary food sources of calcium also varied by region among the elderly women. It was milk (11.2\%) in urban elderly residents, but it was Chinese cabbage kimchi $(10.1 \%)$ in rural elderly residents. The urban residents reported high intake of milk, which is a calcium-rich food source with a high absorption rate. The intake ratio of calcium to phosphorus in the urban elderly men (0.45:1) was significantly higher than that in the rural elderly men (0.43:1). The higher calcium intake from milk in the urban elderly than in the rural elderly might be explained by socioeconomic factors. Unlike rice or vegetables, milk needs to be purchased from stores in most cases, because home production of milk is very challenging. However, accessibility to grocery stores for food purchase is lower in rural areas than in urban areas [44], possibly resulting in relatively low calcium intake from milk in the rural elderly. These differences in calcium intake and food sources of calcium between the urban and rural elderly are also expected to affect the onset and management of chronic diseases in the elderly.

Phosphorus is the second largest mineral in the human body after calcium and is rich in animal foods, such as meat, fish, eggs, and milk, and also in plant sources, such as nuts, vegetables, grains, and tofu. Food sources of phosphorus are abundant in Korean diet and, therefore, the percentage of participants who consumed phosphorus below the EAR was $17.9 \%$, which was lower than that of calcium at $67.4 \%$ [5]. In the present study, phosphorus intake was significantly higher in the 
urban elderly than in the rural elderly, especially the ratio of women rural residents who consumed phosphorus and calcium below the EAR was $40.8 \%$ and $88.1 \%$, respectively. Hence, it is necessary to prepare plans to promote adequate intake of calcium and phosphorus in rural elderly women. In this study, supplementary analysis was performed on the each mineral intake and the risk ratio of chronic diseases in urban and rural elderly populations (see Tables S1-S4) to discover that the calcium and phosphorus intake significantly lowered the risk of hypercholesterolemia in elderly men living in urban areas. Additionally, phosphorus intake lowered the risk of hyperglycemia and, thus, homeostasis control of calcium and phosphorus is considered to be important. Calcium combines with fatty acids and bile in the small intestine to inhibit fat absorption, indicating calcium's effect on lowering cholesterol levels in blood [49]. Based on previous studies, this study presented a negative correlation between calcium intake and hypercholesterolemia; however, the results were inconsistent between urban and rural areas. Along with personal characteristics, urban-rural differences in factors, such as food consumption behavior, food accessibility, and the level of health-nutrition services, lead to differences in the relationship between dietary intake and chronic diseases in urban and rural areas. Therefore, considerably, more systematic studies are needed on the relationship between chronic diseases and calcium and phosphorous intake in urban and rural elderly populations in addition to further investigations of detailed components affecting urban and rural health and dietary intakes.

Potassium has been reported to be protective against hypotension in several epidemiological and clinical studies [50], and white rice, vegetable, kimchi, and fruits are the main sources of potassium in Korea [51]. In this study, the intake of potassium per $1000 \mathrm{kcal}$ of energy intake was significantly higher in the urban elderly than in the rural elderly. This finding is consistent with a large epidemiological study performed in Korea [23] among 40-64-year-old adults. A Polish study also showed that urban inhabitants tended to have higher potassium intake than rural inhabitants [52]. The analysis of potassium food sources in the present study revealed that the cumulative percentage of potassium intake from a total of 10 foods was lower in the urban elderly than in the rural elderly, which implies that the urban elderly consume potassium from more diverse sources than the rural elderly. A recent study on participants aged 50 and older having low calcium intake suggested that potassium intake is beneficial to skeletal health [53], and another previous study revealed that lack of potassium intake was linked to an increased risk of hypertension [54]. Potassium is helpful in preventing chronic diseases, such as hypertension and osteoporosis. However, the analysis on gender differences in this study showed that potassium intake rate as compared to AI was $85.2 \%$ in elderly men aged 65 years and older, but $68.2 \%$ in women of the same age range, indicating inadequate potassium intake of elderly women (data not shown). In the rural elderly women, the potassium intake was only $64.1 \%$ of AI, while sodium intake was $134.3 \%$ of GI, showing inappropriate ratio. Additionally, the rural elderly had lower potassium intake and also had limited food sources of potassium compared to the urban elderly. Hence, it is necessary to develop plans to increase the potassium intake among the rural elderly in the future. It is important to note the limitations of this study. First, this study used the 24-h recall method to investigate nutrient intake. This study used raw data from KNHANES, a national nutrition survey, and the shortcomings of a $24-\mathrm{h}$ recall method in the raw data are also applicable to this study. Nevertheless, a stratified and clustered sampling method used for the KNHANES sample design ensured the enhanced representativeness of sample population. Second, the present study was a cross-sectional study and there were difficulties in interpreting causal relationships. Third, the study did not evaluate mineral intake from drinking water due to the characteristic of KNHANES data. The KNHANES surveyed water intake as a whole, including pure water and some teas, such as barley tea and corn tea, which Koreans often drink in lieu of pure water [33]. Thus, further assessment on the mineral intake from drinking water is required in future studies. Fourth, this study analyzed mineral intakes of the Korean elderly and, thus, it is thought to be difficult to generalize the study results to the world population. Fifth, several less-salient factors regarding food purchasing behaviors and food environments were not considered in the study. Differences in nutrients and food sources between urban and rural areas may be closely related to food purchasing environment [55]. However, 
the KNHANES raw data barely included information regarding food purchasing environment, and this generated limitations in scientific interpretation of research results, if any.

This study has several strengths at the same time. First, this is the first comprehensive study that systematically analyzed mineral intake of the urban-rural elderly utilizing a national nutrition survey, evaluating intake rate as compared to DRIs, and identifying the food sources of the minerals. Bigger sample population was analyzed than the previous studies to increase statistical power of the present study data [22]. Second, in an effort to eliminate possible biases in the study results, socio-demographic variation, in which differences exist between urban and rural settings, was controlled in the analysis. Third, the previous studies $[10,14,15]$ mostly used nutritional screening indicators for analysis, but this study assessed the actual mineral intake of urban-rural elderly as minerals are essential for elderly health, identifying vital minerals for them, in order to compare nutritional status in the elderly between urban and rural areas. These study results are supposedly of great use as baseline data for nutrition education for health management in rural elderly or for the establishment of health policies. Therefore, further studies are needed to evaluate comprehensive and multi-level variables related to meal intake in the elderly between urban and rural areas. For example, the differences of meal and nutrient intake between the urban and rural elderly would be interpreted in a more systematic way if the number of foods consumed at each meal and the dish-based intake status are known. In addition, a thorough investigation is necessary for food supply and demand variables along with environmental variables related to nutrient intake, especially minerals, among the urban-rural elderly.

\section{Conclusions}

Our study shows that the intake of calcium, phosphorus, and potassium of the rural elderly in Korea was significantly lower than that of the urban elderly. The rural elderly showed more exacerbated status of mineral intake, which resulted in a lower intake ratio as compared to RNI of minerals than the urban elderly did. Additionally, regarding the main food sources contributing to calcium intake and absorption, the rural elderly indicated poor intake of calcium rich food as compared to the urban elderly. Therefore, based on the results of this study, it is necessary to prepare a nutrition policy and implement a nutrition program to increase the mineral intake of rural elderly. Moreover, nutrition education for elderly in rural areas should focus on the mineral intake, such as calcium and potassium, which are necessary for the prevention and management of chronic diseases. Further studies should be carried out to procure more detailed data in order to improve the mineral nutritional status in the urban-rural elderly through the investigation of detailed socio-demographic factors, multifaceted examination of dietary factors, and measurements of clinical biomarkers.

Supplementary Materials: The following are available online at http://www.mdpi.com/1660-4601/17/10/3415/s1. Table S1. Odds ratio of hypertension and mineral intake levels of rural and urban Korean elderly, Table S2. Odds ratio of hypercholesterolemia and mineral intake levels of rural and urban Korean elderly, Table S3. Odds ratio of hyperglycemia and mineral intake levels of rural and urban Korean elderly, Table S4. Odds ratio of hypertriglyceridemia and mineral intake levels of rural and urban Korean elderly.

Author Contributions: Both J.-M.K. and Y.-J.B. contributed to the study design and management, performed statistical analyses, and drafted the manuscript. Both authors read and approved the final manuscript. All authors have read and agreed to the published version of the manuscript.

Funding: This research received no external funding.

Acknowledgments: This study was provided with data from the Korea Centers for Disease Control and Prevention, Republic of Korea.

Conflicts of Interest: The authors declare no conflict of interest.

\section{References}

1. World Health Organization. Ageing and Health. Available online: https://www.who.int/news-room/factsheets/detail/ageing-and-health (accessed on 31 January 2020).

2. Statistics Korea. 2018 Elderly Statistics; Statistics Korea: Daejeon, Korea, 2019. 
3. Bowling, A.; Gabriel, Z.; Dykes, J.; Dowding, L.M.; Evans, O.; Fleissig, A.; Banister, D.; Sutton, S. Let's ask them: A national survey of definitions of quality of life and its enhancement among people aged 65 and over. Int. J. Aging Hum. Dev. 2003, 56, 269-306. [CrossRef] [PubMed]

4. World Health Organization. Preventing Chronic Diseases: A Vital Investment. Available online: http: //www.who.int/chp/chronic_disease_report/en/ (accessed on 2 February 2020).

5. Ministry of Health and Welfare \& Korea Centers for Disease Control and Prevention. Korea Health Statistics 2018: Korea National Health and Nutrition Examination Survey (KNHANES VII-3); Korea Centers for Disease Control and Prevention: Cheongju, Korea, 2019.

6. Landi, F.; Liperoti, R.; Lattanzio, F.; Russo, A.; Tosato, M.; Barillaro, C.; Bernabei, R.; Onder, G. Effects of anorexia on mortality among older adults receiving home care: An observation study. J. Nutr. Health Aging 2012, 16, 79-83. [CrossRef] [PubMed]

7. Morley, J.E. Undernutrition in older adults. Fam. Pr. 2012, 29, i89-i93. [CrossRef] [PubMed]

8. Durazzo, M.; Campion, D.; Fagoonee, S.; Pellicano, R. Gastrointestinal tract disorders in the elderly. Minerva Med. 2017, 108, 575-591. [CrossRef] [PubMed]

9. Poulia, K.A.; Yannakoulia, M.; Karageorgou, D.; Gamaletsou, M.; Panagiotakos, D.B.; Sipsas, N.V.; Zampelas, A. Evaluation of the efficacy of six nutritional screening tools to predict malnutrition in the elderly. Clin. Nutr. 2012, 31, 378-385. [CrossRef] [PubMed]

10. Torres, M.J.; Dorigny, B.; Kuhn, M.; Berr, C.; Barberger-Gateau, P.; Letenneur, L. Nutritional status in community-dwelling elderly in France in urban and rural areas. PLoS ONE 2014, 9, e105137. [CrossRef] [PubMed]

11. Larrieu, S.; Letenneur, L.; Berr, C.; Dartigues, J.F.; Ritchie, K.; Alperovitch, A.; Tavernier, B.; Barberger-Gateau, P. Sociodemographic differences in dietary habits in a population-based sample of elderly subjects: The 3C study. J. Nutr. Health Aging 2004, 8, 497-502.

12. Wei, J.M.; Li, S.; Claytor, L.; Partridge, J.; Goates, S. Prevalence and predictors of malnutrition in elderly Chinese adults: Results from the China Health and Retirement Longitudinal Study. Public Health Nutr. 2018, 21, 3129-3134. [CrossRef]

13. Hamamatsu, Y.; Goto, C.; Nishitani, M.; Shimadate, R.; Ueno, J.; Kusakari, Y.; Umezaki, M. Associations between neighborhood food environments and deficient protein intake among elderly people in a metropolitan suburb: A case study in Kisarazu city, Japan. Am. J. Hum. Biol. 2017, 29, e23043. [CrossRef]

14. Kostka, J.; Borowiak, E.; Kostka, T. Nutritional status and quality of life in different populations of older people in Poland. Eur. J. Clin. Nutr. 2014, 68, 1210-1215. [CrossRef]

15. Chen, S.H.; Cheng, H.Y.; Chuang, Y.H.; Shao, J.H. Nutritional status and its health-related factors among older adults in rural and urban areas. J. Adv. Nurs. 2015, 71, 42-53. [CrossRef] [PubMed]

16. Han, S.J.; Kim, H.J.; Kim, D.J.; Lee, K.W.; Cho, N.H. Incidence and predictors of type 2 diabetes among Koreans: A 12-year follow up of the Korean Genome and Epidemiology Study. Diabetes Res. Clin. Pract. 2017, 123, 173-180. [CrossRef] [PubMed]

17. Kim, S.W.; Bae, K.H.; Seo, J.B.; Jeon, J.H.; Lee, W.K.; Lee, I.K.; Kim, J.G.; Park, K.G. Association between household size, residential area, and osteoporosis: Analysis of 2008 to 2011 Korea National Health and Nutrition Examination Survey. Korean J. Intern. Med. 2016, 31, 712-721. [CrossRef] [PubMed]

18. Chun, J.D.; Ryu, S.Y.; Han, M.A.; Park, J. Comparisons of health status and health behaviors among the elderly between urban and rural areas. J. Agric. Med. Commun. Health 2013, 38, 182-194. [CrossRef]

19. Campos, H.; Willett, W.C.; Peterson, R.M.; Siles, X.; Bailey, S.M.; Wilson, P.W.; Posner, B.M.; Ordovas, J.M.; Schaefer, E.J. Nutrient intake comparisons between Framingham and rural and Urban Puriscal, Costa Rica. Associations with lipoproteins, apolipoproteins, and low density lipoprotein particle size. Arter. Thromb. 1991, 11, 1089-1099. [CrossRef]

20. Arjuna, T.; Soenen, S.; Hasnawati, R.A.; Lange, K.; Chapman, I.; Luscombe-Marsh, N.D. A cross-sectional study of nutrient intake and health status among older adults in Yogyakarta Indonesia. Nutrients 2017, 9 , 1240. [CrossRef]

21. Pang, S.J.; Jia, S.S.; Man, Q.Q.; Song, S.; Li, Y.Q.; Song, P.K.; Zhao, W.H.; Zhang, J. Dietary cholesterol in the elderly Chinese population: An analysis of CNHS 2010-2012. Nutrients 2017, 9, 934. [CrossRef] 
22. Lee, Y.; Choi, Y.; Park, H.R.; Song, K.H.; Lee, K.E.; Yoo, C.H.; Lim, Y.S. Comparative analysis of dietary behavior and nutrient intake of elderly in urban and rural areas for development of "Village Lunch Table" program: Based on 2014 Korea National Health and Nutrition Examination Survey data. J. Nutr. Health 2017, 50, 171-179. [CrossRef]

23. Lee, S.; Shin, Y.; Kim, Y. Risk of metabolic syndrome among middle-aged Koreans from rural and urban areas. Nutrients 2018, 10, 859. [CrossRef]

24. Lim, H.; Lee, H.J.; Choue, R.; Wang, Y. Trends in fast-food and sugar-sweetened beverage consumption and their association with social environmental status in South Korea. J. Acad. Nutr. Diet. 2018, 118, 1228-1236. [CrossRef]

25. Kim, Y.; Seo, S.; Kwon, O.; Cho, M.S. Comparisons of dietary behavior, food intake, and satisfaction with food-related life between the elderly living in urban and rural areas. Korean J. Nutr. 2012, 45, 252-263. [CrossRef]

26. Park, M.Y.; Park, J.Y.; Park, P.S. Nutrition states and related factors of female elderly according to residence. J. East Asian Soc. Dietary Life 2015, 25, 39-48. [CrossRef]

27. Shlisky, J.; Bloom, D.E.; Beaudreault, A.R.; Tucker, K.L.; Keller, H.H.; Freund-Levi, Y.; Fielding, R.A.; Cheng, F.W.; Jensen, G.L.; Wu, D.; et al. Nutritional considerations for healthy aging and reduction in age-related chronic disease. Adv. Nutr. 2017, 8, 17-26. [CrossRef] [PubMed]

28. Chen, Y.; Strasser, S.; Cao, Y.; Wang, K.S.; Zheng, S. Calcium intake and hypertension among obese adults in United States: Associations and implications explored. J. Hum. Hypertens. 2015, 29, 541-547. [CrossRef]

29. Nordin, B.E. Calcium and osteoporosis. Nutrition 1997, 13, 664-686. [CrossRef]

30. Kelly, O.J.; Gilman, J.C.; Boschiero, D.; Ilich, J.Z. Osteosarcopenic obesity: Current knowledge, revised identification criteria and treatment principles. Nutrients 2019, 11, 747. [CrossRef]

31. Lotz, M.; Zisman, E.; Bartter, F.C. Evidence for a phosphorus-depletion syndrome in man. N. Engl. J. Med. 1968, 278, 409-415. [CrossRef]

32. Mills, K.T.; Stefanescu, A.; He, J. The global epidemiology of hypertension. Nat. Rev. Nephrol. 2020, 16, 223-237. [CrossRef]

33. Ministry of Health and Welfare \& Korea Centers for Disease Control and Prevention. Korea Health Statistics 2015: Korea National Health and Nutrition Examination Survey (KNHANES VI-3); Korea Centers for Disease Control and Prevention: Cheongju, Korea, 2016.

34. Kweon, Y.; Kim, M.J.; Jang, Y.; Kim, K.; Kim, S.; Choi, C.; Chun, Y.H.; Oh, K. Data resource profile: The Korea National Health and Nutrition Examination Survey (KNHANES). Int. J. Epidemiol. 2014, 43, 69-77. [CrossRef]

35. Willett, W. Nutritional Epidemiology, 3rd ed.; Oxford University Press: New York, NY, USA, 2013.

36. Friedewald, W.T.; Levy, R.I.; Fredrickson, D.S. Estimation of the concentration of low-density lipoprotein cholesterol in plasma, without use of the preparative ultracentrifuge. Clin. Chem. 1972, 18, 499-502. [CrossRef]

37. National Rural Resources Development Institute. Korean Food Composition Table, 8th ed.; Rural Development Administration: GyeongGi-Do, Korea, 2011; ISBN 978-89-363-1289-3.

38. Ministry of Health and Welfare. The Korean Nutrition Society, Dietary Reference Intakes for Koreans 2015. Available online: http://www.kns.or.kr/FileRoom/FileRoom_view.asp?idx=79\&BoardID=Kdr (accessed on 9 January 2020).

39. Oh, M.H.; Choe, J.; Kim, Y.; Lee, S.E.; Paik, H.Y.; Jang, M.J. Customer perception and expert assessment in restaurant food environment by region-Focused on restaurants in Suwon, Hwaseong city. J. Nutr. Health 2014, 47, 463-474. [CrossRef]

40. Rodrigues, L.P.; Carvalho, R.C.; Maciel, A.; Otanasio, P.N.; Garavello, M.E.; Nardoto, G.B. Food insecurity in urban and rural areas in central Brazil: Transition from locally produced foods to processed items. Ecol. Food Nutr. 2016, 55, 365-377. [CrossRef] [PubMed]

41. Story, M.; Kaphingst, K.M.; Robinson-O’Brien, R.; Glanz, K. Creating healthy food and eating environments: Policy and environmental approaches. Annu. Rev. Public Health 2008, 29, 253-272. [CrossRef] [PubMed]

42. Statistics Korea. Census of Agriculture, Forestry and Fisheries. Available online: http://kostat.go.kr/portal/ korea/kor_nw/1/8/6/index.board?bmode=read\&aSeq=374233 (accessed on 3 February 2020).

43. Liberatos, P.; Link, B.G.; Kelsey, J.L. The measurement of social class in epidemiology. Epidemiol. Rev. 1988, 10, 87-121. [CrossRef] 
44. Liese, A.D.; Weis, K.E.; Pluto, D.; Smith, E.; Lawson, A. Food store types, availability, and cost of foods in a rural environment. J. Am. Diet Assoc. 2007, 107, 1916-1923. [CrossRef]

45. McDonald, J.; Quandt, S.A.; Arcury, T.A.; Bell, R.A.; Vitolins, M.Z. On their own: Nutritional self-management strategies of rural widowers. Gerontologist 2000, 40, 480-491. [CrossRef]

46. Ha, K.; Kim, K.; Chun, O.K.; Joung, H.; Song, Y. Differential association of dietary carbohydrate intake with metabolic syndrome in the US and Korean adults: Data from the 2007-2012 NHANES and KNHANES. Eur. J. Clin. Nutr. 2018, 72, 848-860. [CrossRef]

47. Feskens, E.J.; Bowles, C.H.; Kromhout, D. Carbohydrate intake and body mass index in relation to the risk of glucose intolerance in an elderly population. Am. J. Clin. Nutr. 1991, 54, 136-140. [CrossRef]

48. Ha, K.; Joung, H.; Song, Y. Inadequate fat or carbohydrate intake was associated with an increased incidence of type 2 diabetes mellitus in Korean adults: A 12-year community-based prospective cohort study. Diabetes Res. Clin. Pract. 2019, 148, 254-261. [CrossRef]

49. Yacowitz, H.; Fleischman, A.I.; Bierenbaum, M.L.; Kritchevsky, D. Calcium and lipid metabolism: Effects of increased dietary calcium on atherosclerosis in rabbits. Trans. N. Y. Acad. Sci. 1971, 33, 344-350. [CrossRef]

50. He, F.J.; MacGregor, G.A. Fortnightly review: Beneficial effects of potassium. BMJ 2001, 323, 497-501. [CrossRef]

51. Lee, H.S.; Duffey, K.J.; Popkin, B.M. Sodium and potassium intake patterns and trends in South Korea. J. Hum. Hypertens. 2013, 27, 298-303. [CrossRef] [PubMed]

52. Suliburska, J.; Bogdański, P.; Duda, G.; Pupek-Musialik, D.; Piątek, J.; Żukiewicz-Sobczak, W. An assessment of dietary intake and state of nutritional in hypertensive patients from rural and urban areas of Greater Poland. Ann. Agric. Environ. Med. 2012, 19, 339-343. [PubMed]

53. Kong, S.H.; Kim, J.H.; Hong, A.R.; Lee, J.H.; Kim, S.W.; Shin, C.S. Dietary potassium intake is beneficial to bone health in a low calcium intake population: The Korean National Health and Nutrition Examination Survey (KNHANES) (2008-2011). Osteoporos. Int. 2017, 28, 1577-1585. [CrossRef]

54. Noh, H.M.; Park, S.Y.; Lee, H.S.; Oh, H.Y.; Paek, Y.J.; Song, H.J.; Park, K.H. Association between high blood pressure and intakes of sodium and potassium among Korean adults: Korean National Health and Nutrition Examination Survey, 2007-2012. J. Acad. Nutr. Diet. 2015, 115, 1950-1957. [CrossRef] [PubMed]

55. Bodor, J.N.; Rose, D.; Farley, T.A.; Swalm, C.; Scott, S.K. Neighbourhood fruit and vegetable availability and consumption: The role of small food stores in an urban environment. Public Health Nutr. 2008, 11, 413-420. [CrossRef]

(C) 2020 by the authors. Licensee MDPI, Basel, Switzerland. This article is an open access article distributed under the terms and conditions of the Creative Commons Attribution (CC BY) license (http://creativecommons.org/licenses/by/4.0/). 